University of Nebraska - Lincoln

DigitalCommons@University of Nebraska - Lincoln

December 2002

\title{
Crab Louse Infestation in Pre-Columbian America
}

F. M. Rick

Escola Nacional de Saúde Pública, Fundação Oswaldo Cruz, Rio de Janeiro, Brazil

G. C. Rocha

Escola Nacional de Saúde Pública, Fundação Oswaldo Cruz, Rio de Janeiro, Brazil

K. Dittmar

Institut für Parasitologie, Universität Leipzig, Germany

C. E. A. Coimbra Jr.

Escola Nacional de Saúde Pública, Fundação Oswaldo Cruz, Rio de Janeiro, Brazil

Karl J. Reinhard

University of Nebraska at Lincoln, kreinhard1@mac.com

See next page for additional authors

Follow this and additional works at: https://digitalcommons.unl.edu/natrespapers

Part of the Natural Resources and Conservation Commons

Rick, F. M.; Rocha, G. C.; Dittmar, K.; Coimbra, C. E. A. Jr.; Reinhard, Karl J.; Bouchet, F.; Ferreira, L. F.; and Araújo, A., "Crab Louse Infestation in Pre-Columbian America" (2002). Papers in Natural Resources. 93. https://digitalcommons.unl.edu/natrespapers/93

This Article is brought to you for free and open access by the Natural Resources, School of at DigitalCommons@University of Nebraska - Lincoln. It has been accepted for inclusion in Papers in Natural Resources by an authorized administrator of DigitalCommons@University of Nebraska - Lincoln. 


\section{Authors}

F. M. Rick, G. C. Rocha, K. Dittmar, C. E. A. Coimbra Jr., Karl J. Reinhard, F. Bouchet, L. F. Ferreira, and A. Araújo 
J. Parasitol., 88(6), 2002, pp. 1266-1267

\title{
Crab Louse Infestation in Pre-Columbian America
}

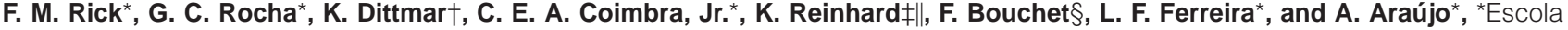 \\ Nacional de Saúde Pública, Fundação Oswaldo Cruz, Rua Leopoldo Bulhões 1480, 21041-210 Rio de Janeiro, Brazil; †Institut für \\ Parasitologie, Universität Leipzig, 04103 Leipzig, Germany; łSchool of Natural Resources Sciences, University of Nebraska, 126 Bessey Hall, \\ Lincoln, Nebraska 68588-0340; §Laboratoire de Paléoparasitologie, EA3308 CNRS ESA 8045, Faculté de Pharmacie, Université de Reims, Rue \\ Cognacq Jay 51, 51096 Reims, France. ||To whom correspondence should be addressed. e-mail: kreinhard1@unl.edu
}

ABStRact: Until now, Pthirus pubis infestation in ancient human populations had only been recorded in the Old World. We found crab lice on South American mummified bodies from the Atacama Desert region. Crab louse eggs were found attached to the pubic hairs of a 2,000-yrold Chilean mummy. Well-preserved adults were found in sediment and clothing from a Peruvian mummy dated 1,000 yr ago. Paleoparasitological evidence expands the knowledge of the distribution of this ectoparasite in ancient populations. As with many other parasites, pubic lice recorded in Andean populations show the antiquity of this parasite in the New World. It is likely that P. pubis entered the continent with early human migration to the New World.

Louse infestation in ancient human populations has been recorded in different geographic regions throughout the world. Greek, Egyptian, Chinese, and other Old World ancient medical texts referred to head and body lice infestation (Hoeppli, 1956; Doby, 1996). The first paleoparasitological studies were carried out by Ruffer (1921) in Egyptian mummies, in which Pediculus humanus was found. Later, South and North American Indian mummies were also found to be infested with lice (Ewing, 1924). In recent studies, louse eggs, nits, and adults have been recovered from the mummified scalps, archaeological sediments, and coprolites (Reinhard, 1990; Araújo et al., 2000).

Here, we describe the first paleoparasitological record of crab louse (P. pubis) infestation in the New World. All existing paleoparasitological discoveries of crab lice have been in Europe from the first century up to the 18th century (Kenward, 1999, 2001). All ancient European specimens are adults found in sediment samples, preserved by anoxic water logging or partial mineralization. There is no record of $P$. pubis from the Old World mummies.

Pthirus pubis is normally restricted to the pubic and perianal hairs, but occasionally other hairy parts of the trunk, legs, arms, and face may be infested (Mueller, 1973; Burgess, 1995). The ectoparasite is sexually transmitted, but close proximity or the use of the same bed or clothing of an infested individual may result in infestation. The crab louse moves very slowly on the human host, remaining attached to the same pubic hair for a long period of time (Burns and Sims, 1988). Although itching and secondary bacterial infection can result from bites, $P$. pubis does not have the same epidemiological significance as does $P$. humanus in typhus transmission (Burgess, 1995).

Two cases of crab louse infestation in South American prehistoric indigenous populations are presented here. Both were recorded in the Atacama Desert, one in Peru and the other in Chile. San Pedro de Atacama in Chile is a small oasis village near the Andean Cordillera. During pre-Columbian times it was a trading center for different cultures from the Pacific coast to the Amazon forest on the opposite side of the Andes. Because it was located in an oasis, the village attracted people and their domestic animals, and diseases as well (Ferreira et al., 2000).

Because of the climatic conditions in Atacama, the driest desert in the world (Berenguer et al., 1985), many mummified bodies have been found in the proximity of the oasis. Some of these mummies are radiocarbon-dated, but the majority have estimated dates based on cultural artifacts or burial accompaniments (Junqueira and Llagostera, 1994).

Thirty-seven mummies from San Pedro de Atacama, dated up to $2,000 \mathrm{yr}$ old, were examined for parasites. All of them date to before

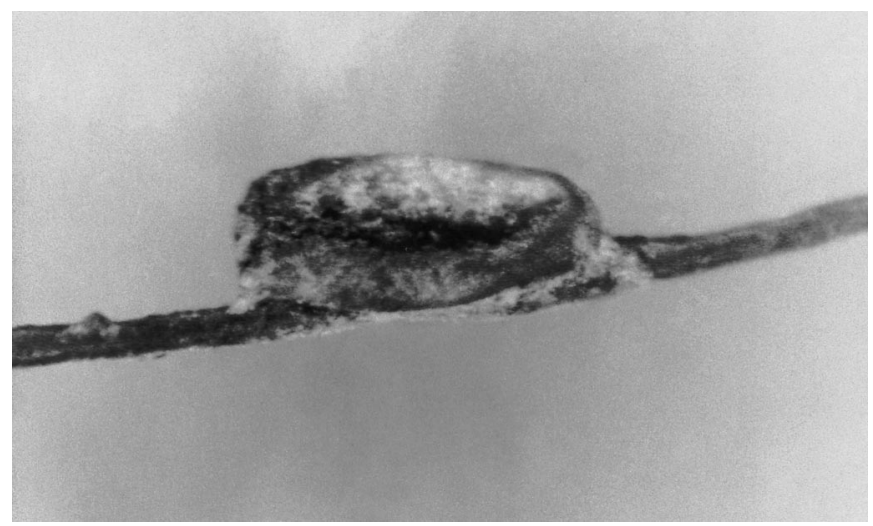

FIgURE 1. Pthirus pubis egg found in pubic hair of a Chilean mummy, Atacama desert. 


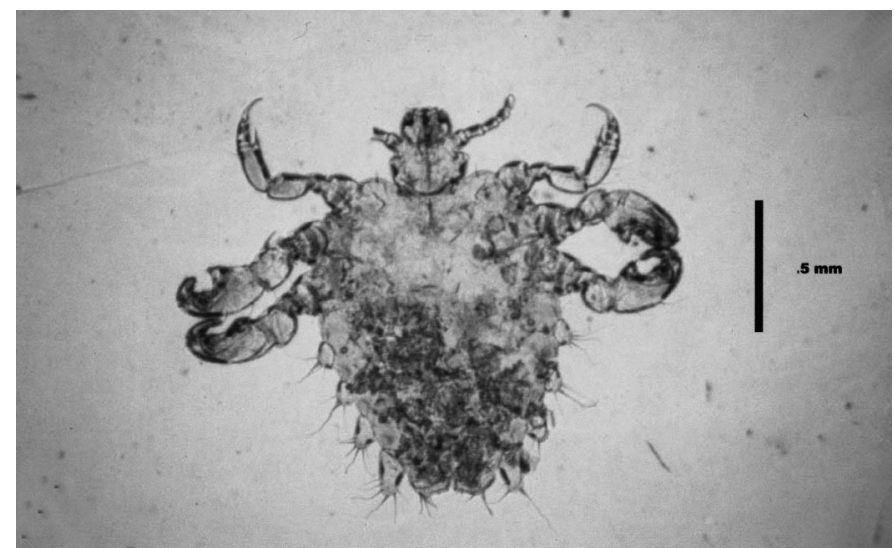

FIGURE 2. Pthirus pubis found in sediment and clothing associated with a mummified human body, Chiribaya Culture, Peru.

the European conquest. Pubic hairs were present in four mummies, and eggs were found attached to the pubic hair in 1 adult male mummy (Fig. 1). The attachment site, morphology, and egg size (1 mm) confirm the diagnosis of $P$. pubis.

The other $P$. pubis specimens came from a Peruvian archaeological site named Chiribaya Baja, dated 1,050 to $800 \mathrm{yr}$ before present. The Chiribaya culture was situated in the south of Peru, in the Moquegua Valley. Two $P$. pubis specimens and several $P$. humanus specimens were found in the pleats of a piece of cloth associated with a female mummy. It was not possible to determine the function of the piece of cloth. One of the $P$. pubis specimens was only fragmentary, but the other is well preserved (Fig. 2). Both are females. The foreleg is quite slender, with a long fine claw (Busvine, 1951). The mid and hind legs are strong with thick claws, and the characteristically compressed abdomen is wider than it is long. The preserved specimen measured 1.63 $\mathrm{mm}$, which lies in the $1.5-$ to $2.0-\mathrm{mm}$ distribution recorded for modern crab lice (Matheson, 1950).

Crab lice are usually attached to the pubic and perianal hairs. It remains unclear why $P$. pubis and $P$. humanus were found in the same piece of cloth. Pubic hair of the mummy could not be found, so no additional information regarding distribution or infestation levels could be provided for paleoepidemiological inferences. Chiribaya mummies are typically buried in textile wrappings, which includes the dead individual's shirt, belt, hat, and other textiles. The textile might have been part of this person's clothing. The finding of $P$. pubis and $P$. humanus is consistent with this hypothesis. The lice possibly moved into the clothing after their host died.

Both findings expand our knowledge of crab lice distribution in prehistoric times in pre-Columbian America. The discovery of crab lice adds to the inventory of parasites that affected Andean peoples. Body lice, head lice, and intestinal parasites such as pinworm, whipworm, the tapeworm Diphyllobothrium pacificum (Reinhard et al., 1986), and Trypanosoma cruzi (Guhl et al., 1999; Ferreira et al., 2000) already had been found in prehistoric human populations from this region. It is quite likely that the interchange of populations between the Andes and the Amazon resulted in the exchange of parasites between the 2 areas. The discoveries of ancient parasites show that prehistoric Americans and
Europeans had more parasites in common than was traditionally thought. Furthermore, there appear to be no morphological differences between archaeological and the present-day $P$. pubis. Their organic conservation allows for further studies in molecular biology aimed at genetic comparisons.

This study was supported by Pronex/CNPq, Capes/Cofecub, and the Fulbright Commission. The authors thank M. A. Costa and A. Llagostera for providing archaeological material.

\section{LITERATURE CITED}

Araújo, A., K. Reinhard, N. M. Serra-Freire, N. Guidon, K. DitTMAR, AND L. F. FERREIRA. 2000. Ten thousand years of head lice infection. Parasitology Today 16: 269.

Berenguer, J., A. Deza, A. Román, and A. Llagostera. 1985. La secuencia de Mirian Tarragó para San Pedro de Atacama: Un test por luminescencia. Revista Chilena de Antropología 5: 17-54.

Burgess, I. F. 1995. Human lice and their management. Advances in Parasitology 36: 271-342.

Burns, D. A., AND T. A. Sims. 1988. A closer look at Pthirus pubis. Journal of Dermatology 118: 497-503.

Busvine, J. 1951. The biology and control of insect pests of medical and domestic importance. Methuen, London, U.K., 243 p.

Doby, J. M. (ED.) 1996. Pous et morpions: Des compagnons de toujours. Bayeussaine, Bayeux, France, 205 p.

EwING, H. E. 1924. Lice from human mummies. Science 1556: 389390 .

Ferreira, L. F., C. Britto, M. A. Cardoso, O. Fernandes, K. ReinHARD, AND A. ARAúJO. 2000. Paleoparasitology of Chagas disease revealed by infected tissues from Chilean mummies. Acta Tropica 75: 79-84.

Guhl, F., G. A. Vellejo, R. Yockteng, F. Cardenas-Arroyo, G. ForNACIARI, B. ArriazA, AND A. C. Aufderheide. 1999. Isolation of Trypanosoma cruzi DNA in 4,000-year-old mummified human tissue from northern Chile. American Journal of Physical Anthropology 108: 401-407.

HoEppli, R. 1956. The knowledge of parasites and parasite infections from ancient times to the 17th century. Experimental Parasitology 5: 398-412.

Junqueira, M. A. C., And A. Llagostera. 1994. Coyo 3: Momentos finales del periodo medio en San Pedro de Atacama. Estudios Atacameños 11: 73-107.

Kenward, H. 1999. Pubic lice (Pthirus pubis L.) were present in Roman and Medieval Britain. Antiquity 73: 911-915.

2001. Pubic lice in Roman and medieval Britain. Trends in Parasitology 17: 167-168.

Matheson, R. 1950. Medical entomology. Comstock Publishing Company Inc., New York, New York, 197 p.

Mueller, J. F. 1973. Pubic lice from the scalp hair: a report of two cases. Journal of Parasitology 59: 943-944.

ReINHARD, K. 1990. Archaeoparasitology in North America. American Journal of Physical Anthropology 82: 145-163.

, U. Confalonieri, B. Herrmann, L. F. Ferreira, and A. AraÚJO. 1986. Recovery of parasite remains from coprolites and latrines: Aspects of paleoparasitological technique. Homo 37: 217239.

Ruffer, M. A. 1921. Studies in the paleopathology of Egypt. The University of Chicago Press, Chicago, Illinois, 372 p. 